\title{
ANALISIS MEKANISME PENGELOLAAN ASURANSI PERTANIAN DI INDONESIA DAN POTENSI DAMPAKNYA TERHADAP APBN ${ }^{1}$
}

\author{
ANALYSIS ON MANAGEMENT MECHANISM OF \\ AGRICULTURAL INSURANCE IN INDONESIA AND THE \\ POTENTIAL IMPACT ON STATE BUDGET
}

\author{
Abdul Aziz \\ Badan Kebijakan Fiskal, Kemeterian Keuangan \\ Jalan DR. Wahidin Raya Nomor 1 Jakarta Pusat, \\ Email: kingabaz@gmail.com
}

Naskah diterima: 26 Februari 2015, revisi pertama: 10 Februari 2016, revisi kedua: 24 Maret 2016.

\begin{abstract}
The agricultural sector is one of the sectors that make an important contribution to the Indonesian economy, therefore each farm and the farmer should have the right of protection, especially in dealing with various issues such as farm business certainty and prices, crop failures, as well as climate change. This is one of the messages that are mandated in Law No. 19 Year 2013 on the Protection and Empowerment of Farmers. Background of this problem came the idea to implement agricultural insurance in Indonesia with the aim to stabilize the income of farmers by reducing the level of losses suffered by farmers because of the risk of losing the crop. This study took some lessons from the implementation of agricultural insurance in other countries and the results of testing the implementation of agricultural insurance in Indonesia in 2013. This study uses descriptive quantitative analysis to recommend management mechanism of agricultural insurance to be applied in Indonesia and mathematicallycalculate the potential impact on the state budget.
\end{abstract}

Keywords: Agricultural insurance, management mechanism of agricultural insurance in Indonesia and the potential impact on the state budget

\begin{abstract}
Abstrak
Sektor pertanian merupakan salah satu sektor yang memberikan kontribusi penting dalam perekonomian Indonesia, oleh karena itu setiap usaha tani dan petani seharusnya mendapat hak perlindungan terutama dalam menghadapi berbagai permasalahan usaha tani seperti kepastian usaha, risiko harga, kegagalan panen, praktek ekonomi biaya tinggi, dan perubahan iklim. Inilah salah satu pesan yang diamanahkan dalam Undang-undang Nomor
\end{abstract}


19 Tahun 2013 Tentang Perlindungan dan Pemberdayaan Petani. Dari latar belakang masalah inilah akhirnya muncul ide untuk menerapkan asuransi pertanian di Indonesia dengan tujuan untuk menstabilkan pendapatan petanimelalui pengurangan tingkat kerugian yang dialami petani karena adanya risiko kehilangan hasil panen. Penelitian ini mengambil beberapa pelajaran dari penerapan asuransi pertanian di negara-negara lain dan hasil uji coba penerapan asuransi pertanian di Indonesia pada tahun 2013. Penelitian ini menggunakan metode analisis deskriptif kuantitatif untuk merekomendasikan mekanisme pengelolaan asuransi pertanian yang akan diterapkan di Indonesia dan menghitungsecara matematis potensi dampaknya terhadap APBN.

Kata kunci: Asuransi pertanian, mekanisme pengelolaan asuransi pertanian di Indonesiadan potensi dampaknyaterhadap APBN

\section{A. PENDAHULUAN}

Salah satu tugas negara adalah melindungi segenap bangsa Indonesia, dan mewujudkan keadilan sosial bagi seluruh rakyat Indonesia, hal ini tersurat dalam pembukaan Undang-Undang Dasar Negara Republik Indonesia Tahun 1945. Jadi setiap warga negara Indonesia (WNI) berhak untuk mendapatkan hak-hak di atas dari negara tidak terkecuali untuk WNI yang memilih jalan hidupnya sebagai seorang petani yangmencari penghidupan di sektor pertanian.

Sektor pertanianmerupakan salah satu sektor yang masih memegang peranan penting di Indonesia. Berdasarkan atas dasar harga berlaku sampai dengan tahun 2012 sektor inimenyumbangkan nilai output PDB sebesar Rp1.190 triliun atau sekitar 14,44\% dari total PDB sekitar Rp8.241 triliun. Sektor ini jugamasih dapat menyerap tenaga kerja Indonesia sekitar 39,96 juta penduduk (Aziz2013, 2014) dan Bappenas, 2013).Setiap petani Indonesia berhak mendapat perlindungan dalam menghadapi segala permasalahannya sepertiadanya risiko harga, kegagalan panen, praktek ekonomi biaya tinggi, dan perubahan iklim. Inilah salah satu ruh yang diamanahkan dalam Undang-undang Nomor 19 Tahun 2013 Tentang Perlindungan dan Pemberdayaan Petani (Aziz, 2014).

Implementasi di beberapa negara di dunia sebenarnya bisa menjadi pelajaran bagi negara Indonesia dalam menerapkan asuransi jenis ini, misalnya dalam menetapkan besaran premi, luasan lahan yang akan diasuransikan, bagaimana mekansime kerja sama dengan perusahaan asuransinya, berapa subsidi premi yang diberikan pemerintah suatu negara kepada petani yang mengikuti program ini, dan lainnya. Yang menjadi masalah di sini adalah bagaimana mekanisme pengelolan asuransi ini dan ketika asuransi ini benar-benar akan diimplementasikan di Indonesia berapa potensi dampak yang akan ditanggung oleh Pemerintah Indonesia, dalam hal ini adalah belanja subsidi premi pada APBN.

Permasalahan yang akan muncul dalam program perlindungan petani (asuransi pertanian) adalah adanya beberapa gap antara aturan dalam perundangan yang ada (terutama UU nomor 19 tahun 2013) dengan kenyataan yang selama ini terjadi serta potensi masalah yang mungkin akan muncul jika undang-undang tersebut diimplentasikan seperti dalam hal koordinasi antar instansi yang selama ini masih lemah, penyediaan sarana dan prasarana pertanian yang masih kurang, dukungan anggaran yang masih minim dalam APBN dan APBD terhadap pelaksanaan program perlindungan petani yang belum besar, dan lainnya. Secara umum dapat penulis jelaskan beberapa gap dalam program perlindugan petani (asuransi pertanian) seperti dipaparkan pada tabel. 1 di bawah ini. 
Tabel 1.

Potensi Gap Kondisi Ideal dan Implementasi Program Perlindungan Petani (Asuransi Petani)

\begin{tabular}{|c|c|c|c|}
\hline \multirow[b]{2}{*}{ No. } & \multirow[b]{2}{*}{ Poin/Perihal/ Masalah } & \multicolumn{2}{|c|}{ Potensi Gap } \\
\hline & & $\begin{array}{c}\text { Kondisi Ideal/Standar } \\
\text { (UU Nomor } 19 \text { Tahum 2013) }\end{array}$ & $\begin{array}{l}\text { Hasi Uji Coba Implementasi } \\
\text { UU Nomor } 19 \text { Tahum } 2013 \\
\text { dan Potensi Masalah Laimnya }\end{array}$ \\
\hline 1. & $\begin{array}{l}\text { Ketentuan Umum Pro } \\
\text { gram Perlindungan } \\
\text { Petani }\end{array}$ & 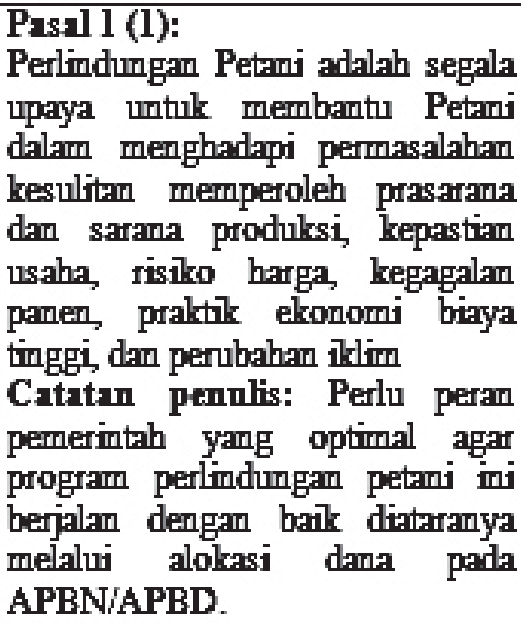 & $\begin{array}{l}\text { Dalam prakteknya, Pemerintah } \\
\text { akan kesulitam melakukam } \\
\text { amamah dari UU ini pada pasal } \\
\text { mi terutama jka dikaitkam } \\
\text { dengan keterbatasan amggaran } \\
\text { (subsidi) yang dialokasi kam } \\
\text { dalam APBN. Dalam uji coba } \\
\text { yang pernah yamg diakukan } \\
\text { pemerim dapat disimpulkan } \\
\text { bahwa peran pemerintah } \\
\text { belum optimal dalam } \\
\text { pengalokasian dama untuk } \\
\text { membayar premi asuramsi. }\end{array}$ \\
\hline 2. & $\begin{array}{l}\text { Prasarana Pertamian } \\
\text { dan Sarama Produksi } \\
\text { Pertamian }\end{array}$ & 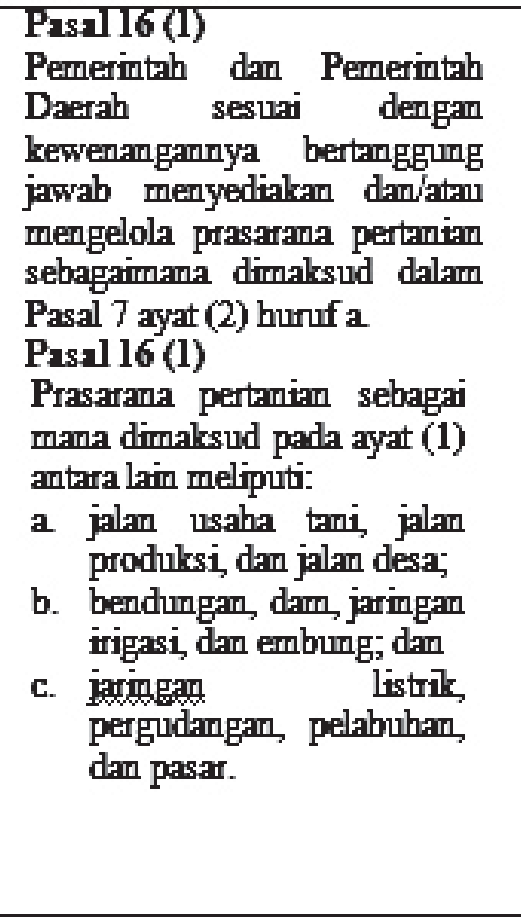 & 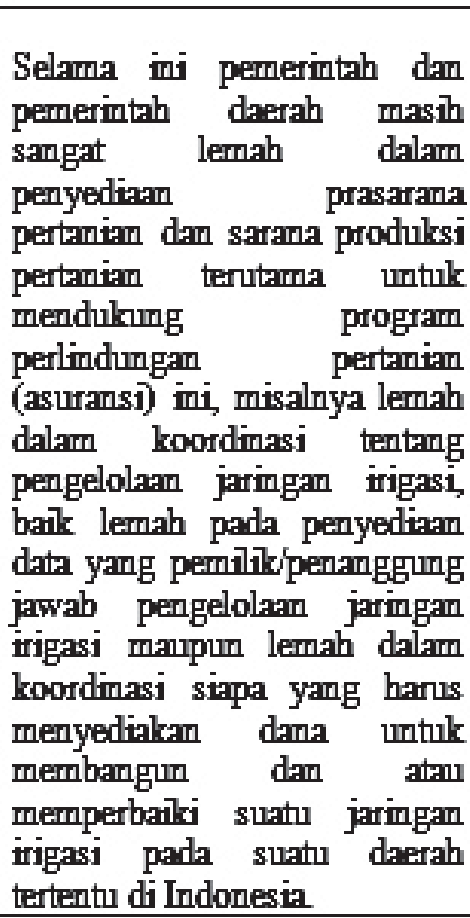 \\
\hline
\end{tabular}

Sumber: Ilustrasi dan Simulasi Penulis

Memperhatikan penjelasan dan tabel. 1 pada bagian latar belakang di atas maka inti permasalahan yang ingin penulis pecahkan pada artikel ini adalah:Bagaimana sebaiknya mekanismepengelolaan asuransi pertanian yang akan diterapkan di Indonesia, dan Bagaimana potensi dampaknyaterhadap belanja pada APBN.Oleh karena itu, tujuan dari penelitian ini adalah untuk: (1) Merekomendasikan format mekanisme pengelolaan asuransi pertanian di Indonesia, dan (2) Menghitung potensi dampaknya secara matematik terhadap belanja subsidi pada APBN jika asuransi ini diimplementasikan di Indonesia. 


\section{B. METODE PENELITIAN}

Mengingat pelaksanaan asuransi pertanian di Indonesia masih dalam tahap percobaan sementara di banyak negara lain telah menerapkan jenis asuransi ini maka penelitian ini menggunakan metodologi penelitian deskriptif kuantitatif terhadap pelaksanaan asuransi (program perlindungan petani) di beberapa negara yang kemudian menurut tingkat eksplanasinya maka digunakanlah metode exploratif (penjajagan) bagaimana format mekanisme asuransi pertanian apabila akan diterapkan di Indonesia dan explorasi terhadap potensi dampaknya terhadap APBN.

\section{Metode Pengumpulan Data}

Data yang digunakan dalam penelitian ini adalah data sekunder dari berbagai sumber. Sumber data utama dari penelitian ini adalah best practices pelaksanaan asuransi pertanian di negara-negara Eropa yang mewakili negara maju, negara-negara Amerika Latin yang mewakili negara-negara berkembang dan negara India sebagai sebuah negara yang mempunyai banyak kesamaan karakter dengan negara Indonesia baik dari segi jumlah penduduk, luas wilayah, luas lahan pertaniannya, iklim dan cuaca, karakter masyarakatnya, dan aspek lainnya. Di samping itu, penelitian ini juga menggunakan data kuantitatif sekunder dari BPS dan lainnya terkait dengan informasi tentang jumlah petani, masa musim tanam, dan lainnya.

\section{Metode Analisis}

Penelitian ini berupaya untuk menggambarkan pelaksanaan asuransi pertanian di negara lain serta mencoba membuat format mekanisme pengelolaan yang tepat untuk dilaksanakan di Indonesia sehingga metode analisis penelitian untuk menjawab tujuan pertama adalah bersifat deskriptif.

Sedangkan untuk mengidentifikasi potensi dampaknya terhadap APBN yaitu dari sisi pengeluaran negara (subsidi) terkait dengan rencana implementasiasuransi pertanian (menjawab tujuan kedua) maka penelitian ini menggunakan analisis kuantitatif secara matematikyaitu dengan menggunakan berbagai variabel kuantitatif yang tersedia sepertidata jumlah petani berdasarkan kepemilikan luasan lahan, jumlah petani perkomoditas khususnya komoditas padi, jagung, kedelai dan tebu (PJKT), data asumsi besaran subsidi premi asuransi yang diberikan pemerintah, dan asumsi frekwensi musim tanam untuk empat komoditas tresebut (PJKT). Sumber data sekunder yang utama yang penulis gunakan adalah Pendataan Usaha Tani (PUT) Tahun 2009 yang diterbitkan oleh Badan Pusat Statistik dan data-data dari hasil uji coba asuransi tahun 2013.

Dari data ini maka diharapkan akan terwujud model simulasi perhitungan potensi pengeluaran negara (khususnya subsidi pada APBN) terkait dengan rencana pelaksanaan asuransi pertanian ini. Adapun formula perhitungan potensi subsidinya dirumuskan secara matematis oleh penulis sebagai berikut:

$$
S_{-} P r_{t} P_{-} \text {Lahan }_{I-J}=\sum_{I-J} \alpha_{1} P \_P J K T_{t-n} \bullet \alpha_{2} M_{-} P J K T_{t-n} \bullet \alpha_{3} P r_{t-n}
$$

Sumber: Ilustrasi dan Simulasi Penulis

Dimana,

S_Pr = Subsidi premi asuransi pertanian pada tahun berjalan;

P_Lahan = Petani berdasarkan luasan lahan, yang dibagi dalam 4 kategori yaitu $<0,5$ hektar, 0,5 h sd 1,99 h, $\leq 1,99$ h, dan $\geq 2$ h; 


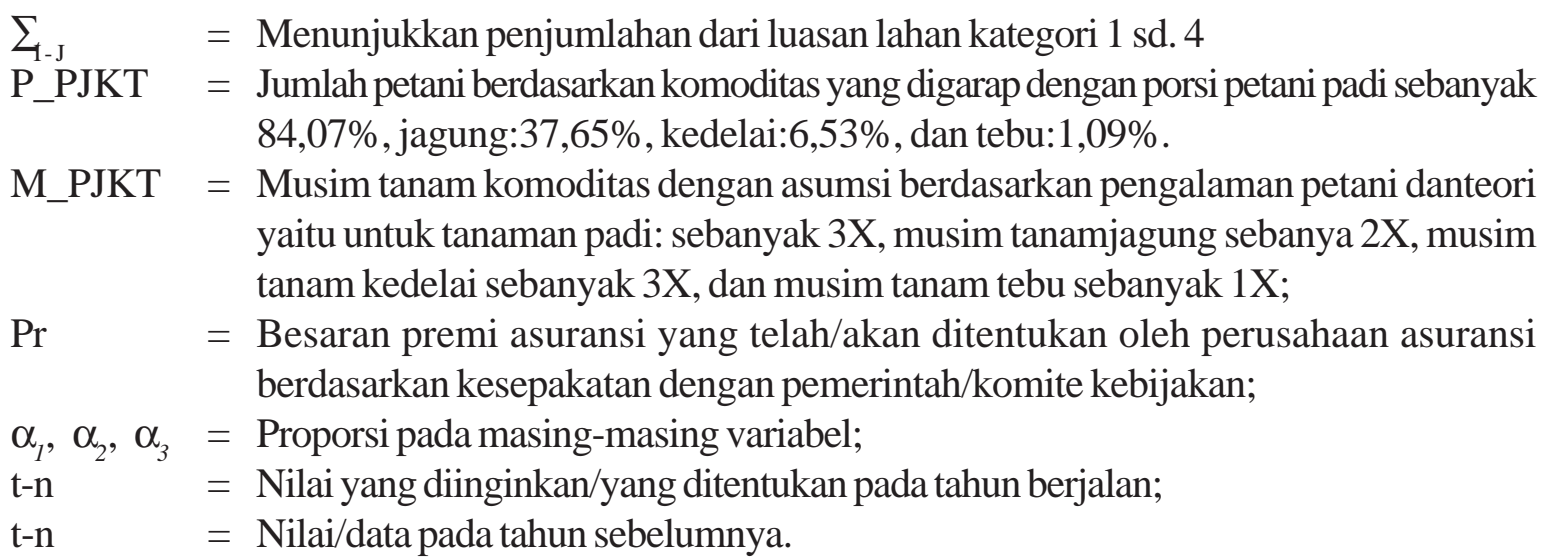

\section{Keterbatasan Penelitian}

Artikel ini masih jauh dari sempurna karena masih ada beberapa keterbatasan yang terdapat dalam penelitian ini, yaitu:

1. Analisis perhitungan besaran subsidi premi pada artikel ini hanya dibatasi pada petani yang menggarap 4 komoditas utama dan tidak mencakup seluruh petani Indonesia. Namun demikian, keterbatasan ini justru bisa menjadi dasar pijakan dalam penghitungan subsidi premi asuransi ini jika akan digunakan data yang lebih besar.

2. Pada artikel ini, penentuan jumlah musim tanamdi suatu lahan pertanian hanya perkomoditas padahal di Indonesia dikenal adanya tiga macam cara bercocok tanam yaitu monokultur, polikultur (tumpang sari) dan rotasi tanaman. Misalnya, pada sistem tumpang sari, suatu lahan dalam satu tahun bisa ditanam beberapa macam tanaman secara bergantian jadi tidak harus padi saja, jagung saja danseterusnya. Di samping itu, penentuan jumlah musim tanam terkadang berlainan antar daerah satu dengan daerah lainnya, namun pada artikel ini karakter setiap daerah dianggap sama;

3. Tidak mencakup semua kategori luasan lahan yang dimiliki oleh petani yang tidak terdata di Pendataan Usaha Tani yang dilakukan oleh Badan Pusat Statistik (PUT BPS (2009)), misalnya ada petani Indonesia yang mungkin mempunyai lahan melebihi 2 hektar, lebih dari 5 hektar, lebih dari 10 hektar, dan seterusnya.

\section{KERANGKA KONSEPTUAL}

\section{Asuransi Pertanian}

Asuransi pertanian menurut Undang-Undang Nomor 19 Tahun 2013 adalah perjanjian antara petani dan pihak perusahaan asuransi untuk mengikatkan diri dalam pertanggungan risiko usaha tani.Adapun tujuan asuransi pertanian adalah untuk memberikan perlindungan kepada petani dalam bentuk bantuan modal kerja jika terjadi kerusakan tanaman atau gagal panen sebagai akibat risiko bencana alam, serangan organisme pengganggu tumbuhan, wabah penyakit menular, dampak perubahan iklim, dan/atau jenis risiko lainnya. Sehingga petani tetap bisa melakukan usaha tani, yaitu menanam kembali setelah terjadi gagal panen. (Insyafiah dan Indria Wardhani, 2014).

Asuransi pertanian ditawarkan sebagai suatu mekanisme pembiayaan untuk membagi risiko seperti kegagalan panen yang disebabkan oleh bencana alam atau serangan organisme pengganggu tanaman. Asuransi pertanian berhubungan dengan pembiayaan usahatani dengan cara melakukan pembayaran premi yang dilakukan oleh pihak ketiga dengan jumlah tertentu. (Pasaribu, dkk, 2010). 
Dengan adanya program asuransi pertanian ini, sektor pertanian akan menjadi lebih menarik sehingga diharapkan dapat mengurangi jumlah petani yang beralih profesi dan konversi lahan pertanian juga diharapkan akan menurun dalam beberapa tahun mendatang sehingga kedaulatan pangan, ketahanan pangan, dan swasembada pangan akan dapat diwujudkan (Setiawan dan Sofi, 2014).

\section{Belajar Asuransi Pertanian Dari Negara Lain}

\section{Praktek Asuransi Pertanian Di Negara India}

Produksi pertanian dan pendapatan usaha tani di India juga sering dipengaruhi oleh bencana alam seperti kekeringan, banjir, badai, tanah longsor dan gempa bumi. Kerentanan usaha tani (sektor pertanian) terhadap bencana tersebut diperparah dengan pecahnya epidemi dan bencana buatan manusia seperti kebakaran, penjualan bibit palsu, pupuk dan pestisida, kenaikan harga, dll.

Perkembangan asuransi pertanian di India memang sangat dinamis baik dilihat dari perkembangan tahun demi tahun, dari satu negara bagian ke negara bagian lainnya, dan adanya perkembangan ketentuan-ketentuan yang terkait dengan asuransi pertanian di sana.

Ada beberapa macam jenis asuransi pertanian yang pernah/sedang dipraktekan di India antara lain:Asuransi Pendapatan Usaha Tani; Asuransi Ternak; Selama tahun 2003-2004 sektor swasta menawarkan beberapa produk asuransi di bidang pertanian berdasarkan indikator-indikator kondisi cuaca di India.

Dari sekitar 25 negara bagian yang dipantau oleh S.S Raju dan Ramesh Chand (2008), penulis hanya akan mengambil 5 sampel negara bagian dan nilai total/rata-rata di India serta hanya mengambil beberapa poin ketentuan asuransi yang berlaku di negara tersebut.

Tabel 2.

Beberapa Aturan Asuransi Pertanian Di Negara-Negara Bagian di India

\begin{tabular}{|c|l|c|c|c|c|c|c|c|}
\hline \multirow{2}{*}{ No. } & \multirow{2}{*}{ Negara Bagian } & \multirow{2}{*}{$\begin{array}{c}\text { Area/Petani } \\
\text { (hektar) }\end{array}$} & $\begin{array}{c}\text { Jumlah } \\
\text { Diasuransikanper } \\
\text { (Rs) }\end{array}$ & \multicolumn{2}{|c|}{$\begin{array}{c}\text { Premi Dibayarper } \\
\text { (Rs) }\end{array}$} & \multicolumn{2}{|c|}{$\begin{array}{c}\text { Klaim per } \\
\text { (Rs) }\end{array}$} \\
\cline { 4 - 10 } & & & Petani & Hektar & Petani & Hektar & Petani & Hektar \\
\hline 1 & Andhra Pradesh & 1.52 & 13.211 & 8.675 & 365 & 239 & 965 & 634 \\
\hline 2 & Assam & 0.75 & 8.234 & 10.979 & 207 & 276 & 179 & 239 \\
\hline 3 & Bihar & 1.12 & 11.469 & 10.207 & 250 & 222 & 2.873 & 2557 \\
\hline 4 & Chattisgarh & 2.18 & 5.636 & 2.582 & 146 & 67 & 488 & 224 \\
\hline 5 & Goa & 1.60 & 4.017 & 2.511 & 71 & 44 & 45 & 28 \\
\hline & $\begin{array}{l}\text { Total/Rata-2 } \\
\text { (India) }\end{array}$ & 1.63 & 9.573 & 5.860 & 295 & 180 & 915 & 560 \\
\hline
\end{tabular}

Sumber: S.S Raju dan Ramesh Chand (2008 : 32). Catatan: Rs = Rupee, Mata Uang Negara India

\section{Praktek Asuransi Pertanian di Negara-Negara Amerika Latin}

Sektor Pertanian memegang peranan penting di banyak negara Amerika Latin baik dari sisi ekonomi maupun sisi sosial. Sektor ini memberikan kontribusi 5,5 persen terhadap Produk Domestik Bruto di wilayah ini serta berkontribusi 15,6 persen terhadap total ekspor.

Namun karena perubahan cuaca, serangan hama, dan penyakit tanaman mengakibatkan output dari sektor ini sulit untuk diprediksi dan para petani (produsen) terhalang dari proses pemanenan sehingga mengakibatkan kerugian dalam produksi tanaman.Mengingat adanya risiko-risiko tersebut maka munculah keinginan untuk menyelenggarakan dan mengikuti asuransi pertanian sebagai satu- 
satunya jalan untuk mengelola risiko yang dihadapi. Para petani dan pemerintah setempat merancang strategi pengelolaan risiko untuk menangani adanya risiko dalam produksi pertanian (The World Bank, 2010).

Beberapa poin penting praktek asuransi pertanian di beberapa negara sampel benua Amerika latin dipaparkan penulsi dalam tabel 3 di bawah ini.

Tabel 3.

Beberapa Aturan Asuransi Pertanian di Negara Sampel Benua Amerika Latin

\begin{tabular}{|c|c|c|c|c|}
\hline No. & Negara & $\begin{array}{c}\text { Status Pasar/Struktur } \\
\text { Pasar }\end{array}$ & $\begin{array}{c}\text { Canel Penyampaian } \\
\text { Asuransi Pertanian }\end{array}$ & $\begin{array}{c}\text { Dukumgan Pemerintah } \\
\text { terhadap Asuransi } \\
\text { Pertanian }\end{array}$ \\
\hline 1 & Argentina & $\begin{array}{l}\text { Ada } 26 \text { Perusahaan } \\
\text { Asuransi yang telah } \\
\text { disetujui oleh Badan } \\
\text { Regulator Asuransi. } \\
\text { Komposisinya: } 23 \\
\text { penusahaan asuransi } \\
\text { swasta, 2. Roperasidan } \\
\text { 1dari, Pemerintah. } \\
\text { Hampir semua } \\
\text { Perusahaan Asuransi } \\
\text { tersebut melakukan } \\
\text { reinsurance di pasar } \\
\text { Reasuransi } \\
\text { Intemasional }\end{array}$ & $\begin{array}{|lr|}\text { Untuk Asuransi tanaman } \\
\text { dalam rangka menghadapi } \\
\text { iklim hujan salju (hail crop } \\
\text { insurance) } & \text { ditangani oleh } \\
\text { broker agen yang memiliki } \\
\text { jaringan perusahaan } \\
\text { asuransi r } & \text { (terutama } \\
\text { koperasi). } & \text { Sedangkan } \\
\text { Perusahaan } & \text { Swasta tidak } \\
\text { mempunyair jaringan } \\
\text { pengembangan di daerah } \\
\text { pertanian dan harus } \\
\text { bergantung pada broker } \\
\text { ritel untuk sampai pada } \\
\text { petani }\end{array}$ & $\begin{array}{l}\text { Pemerintah Federal } \\
\text { (melalui the Agricultural } \\
\text { Risk Office-the Ministry } \\
\text { of Agricultur, Livestock } \\
\text { and Pisheries)membantu } \\
\text { penyediaan bantuan } \\
\text { teknis kepada provinsi } \\
\text { dan perusahaan asuransi } \\
\text { dalam mengembangkan } \\
\text { asuransi pertanian. } \\
\text { Bantuan itu berupa } \\
\text { informasi, capacity } \\
\text { building, penelitian dan } \\
\text { pengembangan produk, } \\
\text { serta pemetaaan risiko. }\end{array}$ \\
\hline 2 & Bolivia & 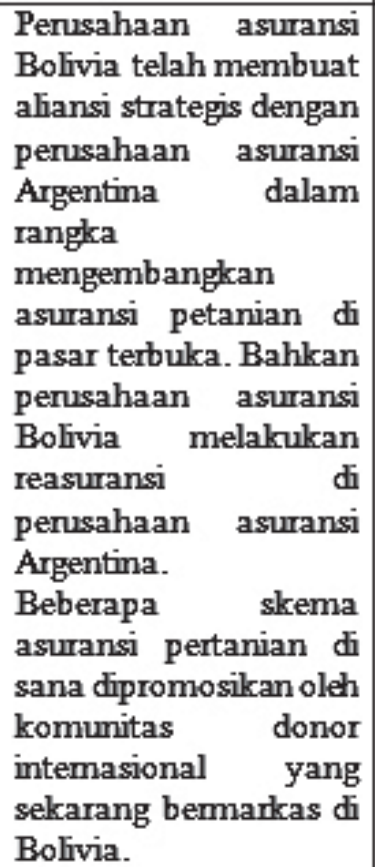 & $\begin{array}{l}\text { Asuransi pertanian di } \\
\text { Bolivia ditangani/dikelola } \\
\text { oleh para broker dan } \\
\text { jaringan } \\
\text { tanaman. }\end{array}$ & 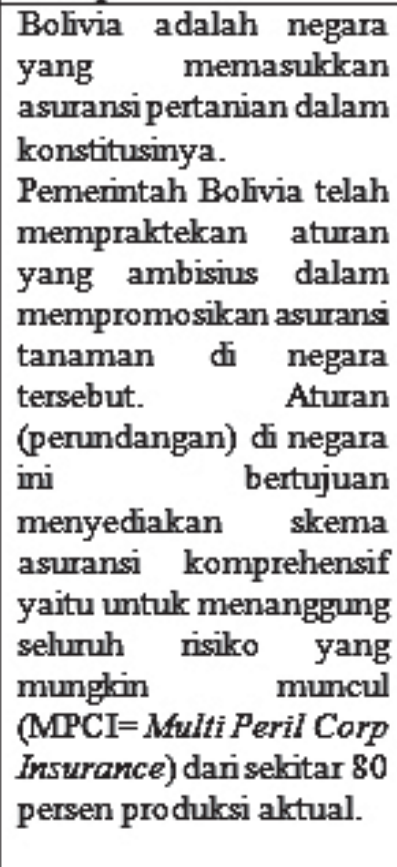 \\
\hline 3 & Brazil & $\begin{array}{l}9 \text { perusahaan asuransi } \\
\text { di Brazil menawarkan } \\
\text { asuransi pertanian dan } \\
\text { semua penusahaan } \\
\text { tersebut adalah dan } \\
\text { swasta. Penusahaan } \\
\text { asuransi yang utama }\end{array}$ & $\begin{array}{l}\text { Instansi/pihak yang } \\
\text { mengelola asuransi di } \\
\text { Brazil tergantungpada jenis } \\
\text { bisnis yang akan } \\
\text { dijalankan. } \\
\text { Misalnya, untuk MPCI } \\
\text { maka pemain utamanya }\end{array}$ & $\begin{array}{l}\text { Sejak 2005 } \text { Pemerintah } \\
\text { Federal telah } \\
\text { memberikan subsidi } \\
\text { premi, begitu pula } \\
\text { dengan Pemerintah Lokal } \\
\text { (SubnationalGovernment } \\
\text { ) telah memberikan }\end{array}$ \\
\hline
\end{tabular}




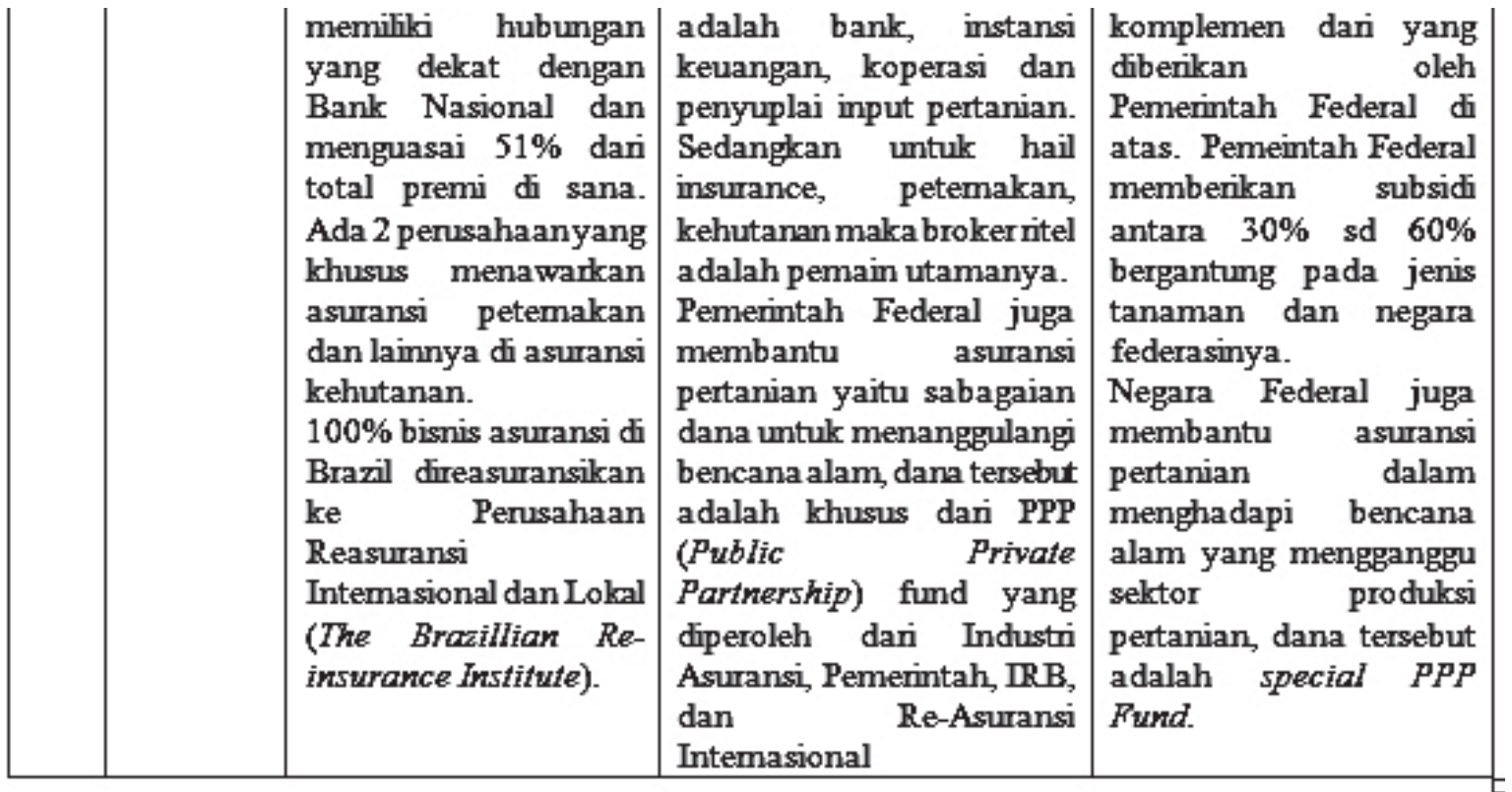

Sumber: The World Bank (2010: 94-101)

\section{Praktek Asuransi Pertanian di Negara-Negara Eropa}

Beberapa negara Eropa telah lama menerapkan asuransi pertanian di wilayahnya masingmasing. Di Spanyol Pemerintah berkolaborasi dengan serikat petani dan perusahaan asuransi untuk menerapkan sistem ini di mana sebagian besar risiko adalah untuk mengcover hasil panen. Asuransi pertanian juga berkembang baik di negara Perancis, Itali, Luxemberg, dan Austria dimana penanganan sebagian besar risiko bergantung pada kontrak pihak-pihak terkait meskipun porsi terbesar adalah menangani risiko hujan salju dan sebagai tambahan adalah untuk meng-cover hasil panen. Sedangkan di Belgia, Ceko, Hungaria, Polandia, Portugal, Slovenia, Slovakia dan Swedia telah menerapkan asuransi risiko yang terpadu dengan hanya risiko hujan salju dan sebagaian kecil dari risiko lainnya saja yang dicover.

Pasar asuransi di Eropa ternyata sangat bervariasi antara satu negara dengan negara lainnya, sebagian dikuasai oleh satu 'pemain' (monopoly), dan kadang hanya ada dua perusahaan dominan yang mengurusi hal yang sangat spesifik di sektor pertanian.

Dari 28 negara yang dijadikan sampel penelitian oleh M.Bielza Diaz-Caneja (2009) dan kawankawan, penulis mengambil 6 negara sampel dan 5 unsur aturan yang sering terdapat dalam aplikasi asuransi pertanian sebagaimana digambarkan pada tabel 4 di bawah ini. Hal ini diharapkan bisa menggambarkan praktek penyelenggaraan asuransi petanian di benua Eropa ini dan dapat dijadikan rujukan dalam penerapan asuransi pertanian di Indonesia. 
Tabel 4.

Beberapa Aturan Asuransi Pertanian di Negara Sampel Benua Eropa

\begin{tabular}{|c|c|c|c|c|c|}
\hline No. & Negara & $\begin{array}{c}\text { Area } \\
\text { Diasuransikan } \\
(1000 \text { hektar) }\end{array}$ & $\begin{array}{c}\text { Jumlah Premi } \\
\text { (million EUR) }\end{array}$ & $\begin{array}{c}\text { Premi/ } \\
\text { Nilai Asuransi } \\
(\%)\end{array}$ & $\begin{array}{c}\text { Subsidi } \\
\text { Asuransi } \\
\text { (million } \\
\text { EUR/\%) }\end{array}$ \\
\hline \hline 1 & Austria & 1,054 & 52,0 & 2,6 & $24 / 46 \%$ \\
\hline 2 & Ceko & 1,074 & 32,0 & 1,8 & $7 / 30 \%$ \\
\hline 3 & Perancis & 3,507 & 211,0 & 1,7 & $5 / 2,4 \%$ \\
\hline 4 & Itali & 976 & 271,2 & 7,4 & $180 / 67 \%$ \\
\hline 5 & Portugal & 298 & 46,9 & 8,4 & $32 / 68 \%$ \\
\hline 6 & Spanyol & 5,850 & 564,7 & 6,3 & $232 / 41 \%$ \\
\hline
\end{tabular}

Sumber: M.Bielza Diaz-Caneja at all (2009: 15)

Faktor-faktor yang menentukan besaran premi pada asuransi pertanian (tanaman) di negaranegara Eropa adalah sebagai berikut:

1. Frekwensi terjadinya risiko baik dari sisi waktu dan luasan lahan yang diasuransikan;

2. Jenis risiko (seperti hujan salju, kekeringan, dll) dan banyaknya risiko yang ditanggung;

3. Tingkat sensitivitas terhadap risiko dari setiap jenis tanaman;

4. Jumlah lahan pertanian/perkebunan yang diasuransikan;

M.Bielza Diaz-Caneja at all (2009): tentang subsidi dari pemerintah setempat terhadap premi asuransi yang dibayarkan oleh peserta asuransi pertanian itu sangat bervariasi bergantung pada kebijakan masing-masing pemerintah dalam menentukan jenis-jenis apa yang akan ditanggung dalam asuransi. Seperti yang terlihat di tabel 1 di atas bahwa masing-masing negara memberikan subsidi premi yang berlainan. Secara persentase pemberian subsidi premi yang terkecil adalah negara Perancis sebesar 2,4 persen dan yang terbesar adalah negara Portugal sebesar 68 persen (Aziz, 2014).Bahkan Sejumlah negara maju, seperti Amerika, Jepang, dan beberapa negara Uni Eropa memberikan subsidi premi asuransi kepada petani rata-rata sebesar 50\%-60\% dari total premi asuransi yang harus dibayar petani. (Adrayani, 2013).

\section{Pelaksanaan Uji Coba UU Nomor 19 Tahun 2013}

Pemerintah telah berencana untuk menyelenggaraan asuransi pertanian agar hasil panen para petani dapat dijamin dengan baik. Adapun realisasinya secara penuh sedang diupayakan di tahun 2014 ini.Pada pelaksanaan program asuransi ini Pemerintah melalui Kementerian Pertanian direncanakan akan melibatkan BUMN Pupuk Indonesia yang tergabung dalam PT Pupuk Indonesia (Persero) serta PT Jasindo.

Pemerintah sebenarnya sudah melakukan uji coba asuransi pertanian pada tahun 2013 di tiga provinsi yakni di Jawa Timur, Jawa Barat, dan Sumatera Selatan. Skema perlindungan saat itu mencakup risiko banjir, kekeringan, dan serangan organisme pengganggu tanaman (OPT). Namun demikian, sosialisasi terhadap uji coba ini dirasakan masih sangat kurang karena banyak petani belum mengetahui adanya program ini.

Uji coba pelaksanaan asuransi pertanian yang menjadi fokus pembahasan dalam artikel ini adalah uji coba di Kabupaten Jombang. Jombang merupakan kabupaten yang memiliki potensi pertanian yang sangat tinggi karena memiliki ketersediaan sumber daya lahan pertanian dan sumber air irigasi yang sangat memadai. Namun, pada tahun 2011 sebagian lahan pertanian di Kabupaten Jombang mengalami serangan OPT wereng batang coklat sehingga terjadi gagal panen. Pada tahun 
2013 dilakukan uji coba program asuransi di kabupaten ini secara terbatas yang dipusatkan di Kecamatan Bareng dengan luasan 750 Ha. Hal ini dikarenakan di Kecamatan Bareng merupakan daerah yang rawan terhadap serangan OPT tikus, yang sampai saat ini masih menjadi momok bagi petani. Adapun sasaran utama dari program asuransi di kecamatan ini adalah petani tanaman padi.

Beberapa poin ketentuan yang diterapkan dalam uji coba ini adalah sebagai berikut:

1. Para peserta (dalam hal ini petani yang mau sebagai peserta) berkewajiban membayar premi sebesar Rp. 180.000,-/hektar/musim tanam;

2. Luasan lahan pertanian yang dapat diikutkan premi asuransi ini adalah luasan sawah yang kurang dari 2 hektar dengan nama petani penggarap sebagai peserta asuransi;

3. Pemerintah akan menanggung 80 persen dari nilai premi tersebut, dalam pelaksanaannya pemerintah dibantu oleh perusahaan dari Jepang yaitu PT. JICA(Japan International Cooperation Agency) untuk menalangi biaya tersebut;

4. Perserta hanya diwajibkan membayar premi sebesar 20 persen atau sebesar Rp. 36.000,-/ hektar/musim tanam;

5. Pembayaran premi dilakukan tiap musim tanam. Misalnya, untuk musim tanam April-September, petani harus membayar premi pada Maret. Dan untuk musim tanam Oktober-Maret, petani harus membayar premi di September;

6. Apabila terjadi kegagalan panen maka peserta asuransi pertanian ini akan mendapatkan hak peggantian kerugian sebesar Rp. 6.000.000,-/hektar dengan syarat bahwa gagal panen tersebut mencapai 75 persen dari luasan lahan garapannya. Nilai tersebut dihitung dari biaya tanam dengan tujuan apabila lahan petani mengalami puso maka petani dapat segera menanam kembali dengan uang pertanggungan tersebut;

7. Apabila petani peserta asuransi tidak mengalami kegagalan panen/puso maka uang premi yang telah dibayarkan tidak dikembalikan ke petani;

8. Seluruh pengelolaan asuransi pertanian ini ditangani oleh PT. Jasindo (Jasa Asuransi Indonesia). Sehingga apabila ada klaim mengenai arusansi ini maka pihak dari PT. Jasindo beserta POPT (Petugas Pengamat Organisme Pengganggu Tanaman). Berdasarkan pemeriksaaan lapangan oleh Petugas pertanian tesebut baru dapat diputuskan apakan petani yang melaporkan telah terkena serangan hama tersebut dapat mengklaim asuransinya apa tidak.(http:// pertanian.jombangkab.go.id, 2014).

Demikianlah praktek ujicoba asuransi pertanian di Indramayu dan di Jombang yang dapat menjadi gambaran bagaimana arah asuransi pertanian ke depannya jika suatu saat benar-benar diimplementasikan di Indonesia.

\section{Teori Kebijakan Publik}

\section{Model Kebijakan Publik George C. Edwards III}

Edwards III (1980:9) dalam Tahir (2011), mengatakan dalam artikelnya bahwa: “In our approach to the study of policy implementation, we begin in the absrtact and ask: What are the precondition for succsesful policy implemetation? What are primary obstacles to succsesfull policy implementation?”

Paling tidak George C. Edwads III menjelaskan bahwa di dalam pendekatan studi implementasi kebijakan maka pertanyaan dasarnya adalah apakah syarat-syarat dasar/ prakondisi agar suatu kebijakan publik itu sukses serta kendala utama apa yang kira-kira akan dihadapi oleh kebijakan publik tersebut jika diimplementasikan di suatu saat nanti. 
Ada empat variabel yang ditawarkan oleh Edward III (1980:10) dalam Tahir (2011) agar suatu kebijakan publik dapat diimplementasikan dengan baik yaitu: Communication, Resourches, Dispotition or Attitudes, and bureaucratic Structure”. Hubungan ke empat variabel tersebut dengan implementasi kebijakan dapat diilustrasikan oleh Edward III pada gambar 1 di bawah ini.

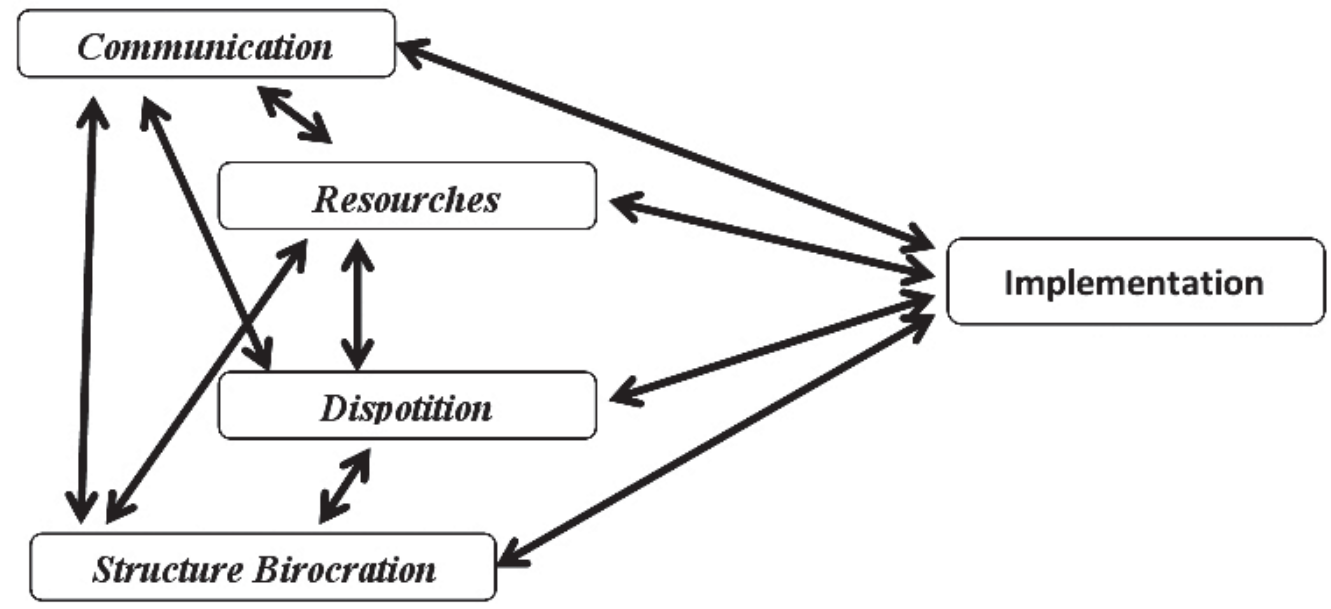

Gambar 1.

Implementasai Kebijakan Menurut George C. Edwards III

Sumber: Edward III (1980) dalam Tahir (2011)

Pada gambar 1 di atas menjelaskan adanya keterkaitan yang erat antar variabel dan tahapan implementasinya sehingga seperti sebuah sistem yang utuh yang tidak dapat dipisahkan satu sama lain. Adapun penjelsan singkat dari 4 variabel itu adalah sebagai berikut:

\section{a. Faktor Komunikasi (Communication)}

Inti dari apa yang disampaiakn oleh Edwards III menurut penulis adalah menegaskan bahwa implementasi kebijakan publik dapat berjalan secara efektif apabila orang/institusi yang bertanggung jawab terhadap implementasi sebuah kebijakan publik tersebut mengetahui apa yang harus dilakukannya.

\section{b. Faktor Sumber Daya (Resourches)}

Sumber daya yang cukup yang diperlukan dalam mengimplementasikan suatu kebijakan adalah seperti (a) implementator dalam jumlah yang tepat dan memiliki keahlian yang diperlukan, (b) informasi yang baik dan relevan tentang cara untuk mengimplementasi-kan suatu kebijakan, (c) adanya kewenangan untuk meyakinkan bahwa kebijakan ini akan dilakukan sesuai dengan tujuan awal, (d) adanya berbagai fasilitas (termasuk bangunan, peralatan, tanah dan persediaan) yang diperlukan, dan alainnya. Jika sumber daya yang diperlukan tidak cukup maka akan berakibat pada (a) sulitnya mengimplementasikan undang-undang yang sebenarnya telah dibuat untuk melandasi kebijakan tresebut, (b) pelayanan tidak akan diberikan secara optimal, dan (c) peraturan-peraturan turunan yang layak dan diperlukan dalam implementasi akan sulit untuk dikembangkan.

\section{c. FaktorSikap Pelaksana (Dispotition/Attitude)}

Kalau implementasi kebijakan diharapkan berlangsung efektif maka ada beberapa sikap/perilaku 
yang harus dilakukan oleh para pelaksana (implementor) kebijakan yaitu (1) harus mengetahui apa yang harus dilakukan,(2) memiliki kapabilitas untuk melaksanakannya, (3) harus mempunyai keinginan untuk melaksanakan kebijakan tersebut.

\section{d. Faktor Struktur Birokrasi (Bureaucratic Structure)}

Terkadang pelaksanan kebijakan masih terhambat oleh inefesiensi struktur birokrasi meskipun sumber daya untuk mengimplemen-tasikan kebijakan telah mencukupi dan para pelaksana mengetahui apa yang harus dilakukan serta bersedia melaksanakannya. Kekakuan dan terkotak-kotaknya organisasi dapat menghambat koordinasi yang diperlukan guna keberhasilan pelaksanan sebuah kebijakan yang mebutuhkan kerja sama dan koordinasi dengan banyak orang/pihak.

\section{Model Kebijakan Publik Charles O. Jones}

Jones (1996 : 166) dalam Tahir (2011) mengatakan bahwa implementasi kebijakan adalah suatu kegiatan yang dimaksudkan untuk mengoperasikan sebuah program dengan memperhatikan tiga aktivitas utama kegiatan, yaitu:

a. Organisasi yaitu pembentukan atau penataan kembali sumber daya, unit-unit serta metode untuk menunjang agar program berjalan,

b. Interpretasi yaitu menafsirkan agar program menjadi rencana dan pengarahan yang tepat dan dapat diterima serta dilaksanakan, dan

c. Aplikasi (penerapan) yaitu berkaitan dengan pelaksanaan kegiatan rutin yang meliputi penyediaan barang dan jasa.

Kaitan interaksi ketiga aktivitas tersebut dengan implementasi kebijakan adalah seperti tergambar pada gambar 2 di bawah ini.

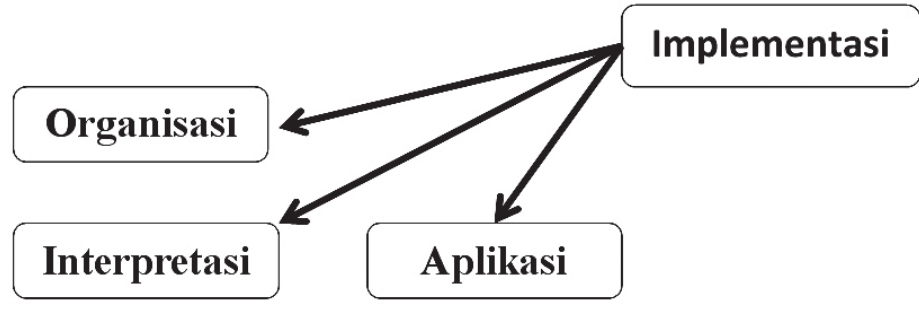

Sumber: Jones (dalam Tahir, 2011).

Gambar 2.

Model Implementasi Kebijakan Charles O. Jones

Dari ilustrasi gambar diatas dapat dijelaskan bahwa sebagai pegangan bagi para pelaksana kebijakan maka harus disadari bahwa implementasi kebijakan itu merupakan suatu periode yang paling beratkarena terkadang dalam periode perumusan kebijakan tidak akan ditemui masalahmasalah pelik namun justru akan munculdi lapangan disaat kebijakan itu diimplementasikan.

\section{HASIL dan PEMBAHASAN}

Pelajaran Best practices dan Uji Coba serta Bagaimana Format Mekanisme PengelolaanAsuransi Pertanian Di Indonesia

Banyak pelajaran yang sebenarnya dapat diambil dari pelaksanaan best practices di negara- 
negara sampel dan uji coba di atas yang dapat dipedomani dalam pelaksanaan asuransi pertanian di Indonesia di masa yang akan datang. Hal-hal yang mungkin bisa diterapkan di Indonesia misalnya adalah variabel yang terkait dengan luasan lahan yang diasuransikan, besaran premi asuransi, subsidi pemerintah, perusahaan re-asuransi.

Luasan lahan pertanian yang diasuransikan di negara lain (terutama di Eropa) adalah sangat bervariasi dari yang terkecil yaitu Austria seluas 1,054 hektar/1.000 hektar sampai yang terluas yang hampir menyentuh seluruh lahan yang ada yaitu di negara Itali, dimana di negara tersebut lahan yang diasuransikan mencapai 976 hektar pada setiap 1.000 hektar. Bagi Indonesia kondisi ini bisa dijadikan pelajaran bahwa sebagian negara-negara Eropa yang sebenarnya bukan negara agraris saja sangat serius dalam melindungi usaha tani maka untuk kasus Indonesia luasan lahan yang diasuransikan sebaiknya bukan hanya berdasarkan kepemilikan (lahan yang kurang dari 2 hektar) tapi juga dihitung berapa target pertahun lahan yang akan diasuransikan sehingga akan terlihat berapa cakupan asuransinya, premi yang harus dibayarkan, beban APBN untuk membayar subsidi premi yang akan dibayarkan pertahunnya, dan perhitungan lainnya.

Pengenaan premi asuransi yang harus dibayarkan petani di negara-negara maju ternyata sangat kecil sekali yaitu kurang dari 8,4 persen dari seluruh nilai yang diasuransikannya, begitu pula praktek pembayaran premi di India secara rata-rata hanya Rs 295/Rs 9537 atau sekitar 3,09 persen. Hali ini berarti hampir sama dengan praktek uji coba asuransi pertanian yang dilakukan di Indonesia.

Di India besaran asuransi, premi, dan klaim berlainan antar satu negara bagian dengan negara bagian lainnya, hal ini kemungkinan besar adalah disesuaikan dengan kondisi khusus dari masingmasing negara bagian tersebut. Praktek ini barangkali bisa diimplementasikan di Indonesia dengan ketentuan yang berbeda di masing-masing daerah/propinsi sesuai dengan karakter wilayah, alam, masyarakat/petani masing-masing. Di negara-negara lain seperti di Eropa juga menunjukkan adanya bantuan/subsidi terhadap premi dengan besaran yang sangat bervariatif, ada yang sangat besar nilai subsidinya seperti Portugal (68 persen dari total premi) dan ada yang sangat kecil seperti Perancis (hanya 2,4 persen dari total premi).

Praktek re-asuransi di beberapa negara di Amerika Latin juga dapat menjadi pelajaran bagi perusahaan-perusahan Indonesia yang sedang dan akan bergerak di bidang ini sehingga beban pertanggungan asuransinya bisa didistribusikan ke perusahaan asuransi/reasuransi lainnya terutama bila terjadi klaim. Beberapa negara telah melakukan hal ini, misalnya dengan bekerja sama dengan melakukan aliansi strategis dengan perusahaan re-asuransi di negara lain yang sudah lebih baik (seperti praktek di negara Bolivia yang melakukan re-asuransi ke perusahaan asuransi Argentina), atau melakukan re-asuransi kepada perusahaan-perusahaan asuransi berskala internasional seperti praktek asuransi di negara Argentina, Brazil, dan lainnya. Meskipun untuk negara-negara berkembang biasanya agak sulit mengkases asuransi pertanian ke pasar reasuransi. Namun, beberapa tahun terakhir perusahaan reasuransi pertanian dan broker internasional menunjukkan minat yang tinggi dalam mengembangkan bisnis ini di negara-negara dengan pendapatan rendah dan sedang terutama di negaranegara dengan penduduk besar seperti China dan India (Mahul and Stutley, 2010).

Bahwa pelaksanaan uji coba asuransi pertanian di Indonesia pada tahun lalu khususnya di Kabupaten Jombang sebenarnya telah menunjukkan keseriusan pemerintah dan pihak terkait dalam melindungi petani dan usahanya dari risiko gagal panen. Jika dilihat dari uji coba di atas, sebenarnya petani diuntungkan dengan kecilnya premi yang harus dibayarkan (hanya 20 persen dari Rp180.000,) permusim tanam dibanding dengan risiko yang mungkin harus ditanggung jika terjadi gagal panen. Kebijakan pemerintah menggandeng JICA dari Jepang juga merupakan langkah terobosan yang baik agar beban APBN dalam menanggung premi asuransi dapat diminimalisir, namun demikian harus bisa dijamin bahwa bantuan premi tersebut adalah bukan untuk mengambil keuntungan hasil 
pertanian Indonesaia di masa yang akan datang dan bukan merupakan bentuk intervensi negara asing terhadap sektor pertanian negara Indonesia.

Memperhatikan penerapan asuransi pertanian di negara-negara di atas dan uji coba di Indonesia maka poin-poin penting yang dapat dipertimbangkan dalam menentukan aturan-aturan asuransi pertanian di Indonesia adalah seperti digambarkan pada Tabel 5 di bawah ini:

Tabel 5.

Ilustrasi Variabel Asuransi Pertanian Yang Dapat Digunakan di Indonesia (Berdasarkan Best practices dan Uji Coba)

\begin{tabular}{|c|c|c|c|}
\hline No & Uraian Aturan & $\begin{array}{c}\text { Besaran/Ukuran/Sasaran/ } \\
\text { Definisi }\end{array}$ & Penjelasan/Keterangan \\
\hline 1. & Sasaran petani & $\begin{array}{l}\text { Pemilik }<0.5 \text { hektar }(\mathrm{h}) \\
\text { atau antara } \geq 0.5 \mathrm{~h} \mathrm{sd.} 2 \\
\text { h. }\end{array}$ & $\begin{array}{l}\text { Berdasarkan luas lahan yang } \\
\text { dimilikinya }\end{array}$ \\
\hline 2. & $\begin{array}{l}\text { Luas area yang } \\
\text { diasuransikan dibanding } \\
\text { luas keseluruhan }\end{array}$ & $\begin{array}{l}100 \mathrm{~h} / 100 \mathrm{~h} \text { artinya } \\
\text { semua diasuransikan } \\
\text { atau } 50 \mathrm{~h} / 100 \mathrm{~h} \text {. }\end{array}$ & $\begin{array}{l}\text { Berdasarkan kondisi lahan, } \\
\text { kemampuan perusahaan asuransi. }\end{array}$ \\
\hline 3. & Besaran premi & $\begin{array}{l}\text { Sesuai kesepakatan } \\
\text { berbagai pihak. }\end{array}$ & $\begin{array}{l}\text { Berdasarkan potensi risiko usaha } \\
\text { tani. }\end{array}$ \\
\hline 4. & $\begin{array}{l}\text { Besaran premi yang } \\
\text { dibayar petani }\end{array}$ & $\begin{array}{l}100 \% \text { dari premi atau } \\
90 \% \text { dari premi, dst }\end{array}$ & $\begin{array}{l}\text { Berdasarkan kemampuan petani, } \\
\text { potensi risiko. }\end{array}$ \\
\hline 5. & $\begin{array}{|lc|}\begin{array}{l}\text { Besaran } \\
\text { dibayar } \\
\text { (subsidi) }\end{array} & \text { premi yang } \\
\end{array}$ & $\begin{array}{l}\text { Nol atau } 10 \% \text { dari premi, } \\
25 \% \text { dari premi. }\end{array}$ & $\begin{array}{l}\text { Berdasarkan kondisi dan } \\
\text { kemampuankeuanganpemerintah, } \\
\text { berdasarkan kemampuan petani. }\end{array}$ \\
\hline 6. & Nilai pertanggungan & $\begin{array}{l}\text { Sesuai kebijakan } \\
\text { perusaaan asuransi. }\end{array}$ & $\begin{array}{l}\text { Bersarkan kemampuan perusahaan } \\
\text { asuransi, potensi risiko, besarnya } \\
\text { premi, banyaknya peserta asuransi } \\
\text { ini, berdasarkan masukan dari } \\
\text { pemerintah/komite kebijakan. }\end{array}$ \\
\hline 7. & Jenis komoditi & $\begin{array}{l}\text { Komoditas yang } \\
\text { dominan digarap petani } \\
\text { di Indonesia. }\end{array}$ & $\begin{array}{l}\text { Berdasarkan program } \\
\text { pembangunan sektor pertanian. }\end{array}$ \\
\hline 8. & Prioritas komoditi & $\begin{array}{lr}\text { Komoditas } & \text { untuk } \\
\text { ketahanan } & \text { pangan } \\
\text { Indonesia. } & \\
\end{array}$ & $\begin{array}{l}\text { Berdasarkan program } \\
\text { pembangunan sektor pertanian. }\end{array}$ \\
\hline 9 & Prioritas wilayah & $\begin{array}{l}\text { Wilayah yang paling } \\
\text { rentanbencana atauyang } \\
\text { paling tidak rentan. }\end{array}$ & $\begin{array}{l}\text { Berdasarkan input/pendapat dari } \\
\text { instansi terkait (seperti BMKG). }\end{array}$ \\
\hline 10. & $\begin{array}{l}\text { Perusahaan/negara } \\
\text { donator }\end{array}$ & $\begin{array}{lr}\text { Yang membantu } \\
\text { pembayaran premi } \\
\text { karena adanya kerjasama } \\
\text { dalam bidang } \\
\text { ekonomi/pertanian. }\end{array}$ & $\begin{array}{l}\text { Tidak ada kepentingan politik dan } \\
\text { menimbukan ketergantungan } \\
\text { kepada negara donor. }\end{array}$ \\
\hline 11. & Avalist(Penjamin) & $\begin{array}{l}\text { Yang membantu } \\
\text { pembayaran premi petani } \\
\text { diluar pemerintah dan } \\
\text { negara/perusahaan } \\
\text { donator. }\end{array}$ & $\begin{array}{l}\text { Berdasarkan kesepakatan dengan } \\
\text { petani melalui poktan atau } \\
\text { gapoktan. }\end{array}$ \\
\hline 11. & Perusahaan re-asuransi & $\begin{array}{l}\text { Sebagai pihak penjamin } \\
\text { perusahaan asuransi }\end{array}$ & $\begin{array}{l}\text { Berdasarkan kesepakatan dengan } \\
\text { perusahaan asuransi dan atas } \\
\text { sepengetahuan dari } \\
\text { Pemerintah/komite kebijakan. }\end{array}$ \\
\hline
\end{tabular}

Sumber: Ilustrasi dan Simulasi penulis 
Memperhatikan uraian dari pengalaman implementasi dan uji coba serta pembahasan di atas, penulis mencoba membuat rekomendasi mekanisme pengelolaan asuransi pertanian dan bagaimana pemerintah Indonesia berperan seperti diilustrasikan pada gambar 1 di bawah ini.

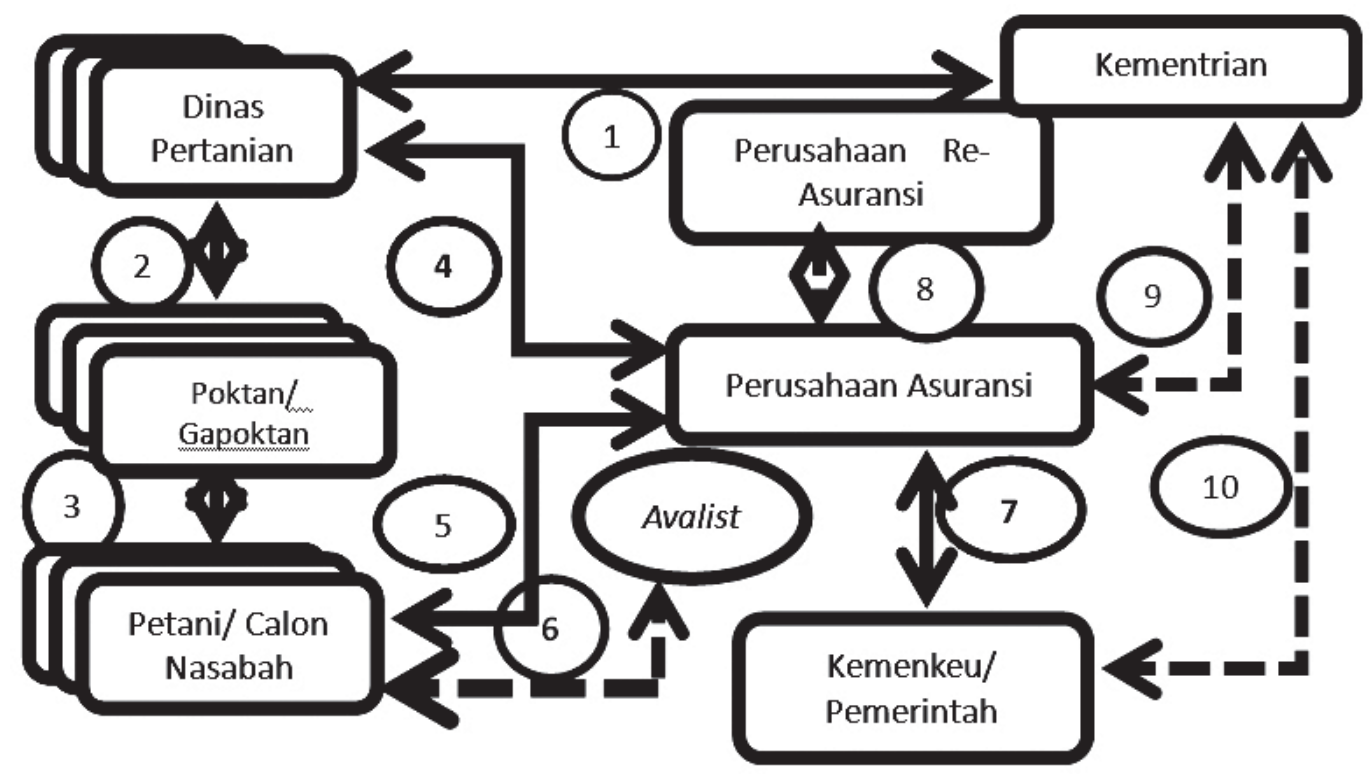

Sumber: Ilustrasi dan Simulasi Penulis

Gambar 3.

Mekanisme Asuransi Pertanian dan Peran Pemerintah Indonesia

Berdasarkan gambar ilustrasi mekanisme di atas maka dapat dijelaskan bahwa adanya hubungan yang saling timbal balik antar berbagai pihak yang terlibat. Secara lebih rinci, gambar tersebut dapat dijelaskan sebagai berikut:

1. Kementerian Pertanian (Kementan) dan Dinas Pertanian (di propinsi/kabupaten/kota) melakukan konsolidasi data tentang jumlah petani, lahan, komoditas unggulan, dan lain sebagainya.

2. Dinas Pertanian memerintahkan kepada kelompok tani (poktan) dan atau gabungan kelompok tani (gapoktan) tentang jumlah petani, lahan, komoditas unggulan, rencana definitif kegiatan kelompok (RDKK), dan lain sebagainya, dan poktan/gapoktan pada akhirnya memberikan data-data tersebut termasuk data petani yang berpartisipasi (menjadi nasabah) pada program asuransi;

3. Poktan/gapoktan memberikan penyuluhan/pembinaan terhadap petani tentang asuransi pertanian, pada sisi lain, para petani yang menjadi nasabah asuansi harus melaporkan kepada poktan/ gapoktanny masing-masing;

4. Dinas pertanian berkoordinasi dengan pihak perusahaan asuransi tentang data petani yang menjadi nasabah asuransi pertanian;

5. Petani sebagai calon nasabah mengikat kerja sama dengan perusahaan asuransi dengan segala hak dan kewajiban yang akan diterima dan diberikan;

6. Petani sebagai calon nasabah dapat mengikat kerja sama dengan pihak avalist (baik perorangan ataupun perusahaan) dengan segala hak dan kewajiban yang akan diterima dan diberikan.

7. Perusahaan asuransi dan Kementerian Keuangan (sebagai wakil pemerintah) mengikat kerja sama tentang besaran premi dansubsidi premi (untuk petani) yang akan dibayarkan pemerintah secara langsung kepadapihak asuransi; 
8. Perusahan asuransi dapat mengikat kerja sama dengan pihak perusahaan re-asuransi dalam hal penjaminan asuransi pertanian;

9. Perusahaan asuransi berkoordinasi dengan Kementerian Pertanian dalam hal pemutakhiran data dan cross check tentang data petani yang menjadi nasabah;

10. Kementerian Keuangan berkoordinasi dengan Kementerian Pertanian dalam hal pemutakhiran data dan cross check tentang data petani yang menjadi nasabah.

Yang juga perlu diperhatikan dalam implementasi kebijakan perlindungan petani, yang dalam hal ini adalah asuransi pertanian di atas, adalah memperhatikan segala aspek yang melekat dari kebijakan tersebut yang saling mempengaruhi satu sama lain sebagaimana disinggung oleh Edward III dan Jones seperti:

1. Adanya komunikasi berbagai pihak yang terlibat kebijakan ini;

2. Adanya sumber daya yang cukup untuk melaksanakan kebijakan ini;

3. Adanya sikap (attitude) yang baik dari para implementor kebijakan ini;

4. Adanya birokrasi (institusi) terkait yang akan menjalankannya;

5. Adanya interpretasi yang jelas terhadap kebijakan ini; dan lainnya.

\section{Potensi Pengaruhnya TerhadapAPBN}

Secara umum, pemerintah Indonesia telah mengalokasikan anggaranbelanja terkait dengan ketahanan pangan dalan APBN. Anggaran belanja tersebut secara garis besar terbagi dalam 4 jenis belanja (sebagai contoh adalah pada APBNP 2014) yaitu:

1. Belanja Pada K/L Sebesar Rp19,48 triliun dengan perincian belanja ketahanan pangan pada Kementan sebesar Rp13,61 triliun dan Kemen PU sebesar Rp5,87 triliun;

2. Belanja Non K/L dalam bentuk Subsidi sebesar Rp48,68 triliun;

3. Belanja Non K/L dalam bentuk Belanja Lain-Lain sebesar Rp3,03 triliun;

4. Belanja Non K/L dalam bentuk transfer ke daerah (DAK) sebesar Rp4,86 triliun. DJA,(2015).

Secara total, alokasi anggaran untuk program ini terus mengalami kenaikan meskipun porsi anggaran untuk program ini masih terbilang kecil yaitu rata-rata sekitar 5,7 persen dari total belanja APBN pada setiap tahunnya. Mengingat manfaat dan output dari program ini yang begitu strategis maka diharapkan Pemerintah dapat menambah alokasi anggaran pada program ini agar pencapaian output yang diinginkan dapat dicapai dengan baik. Salah satu alokasi anggaran yang perlu di tambahkan adalah dari belanja subsidi di bidang pangan yaitu dengan menambahkan poin anggaran subsidi premi asuransi di mana besarannya adalah berkisar antara Rp 500 miliar sampai dengan Rp4,8 triliun sebagai mana dipaparkan dalam tabel 8, 9, dan 10di bawah atau tabel skenario alokasi subsidi premi asuransi pertanian.

Ada beberapa variabel yang dapat digunakan pemerintah dalam menghitung besaran subsidi premi asuransi pertanian, yaitu;

1. Jumlah Rumah Tangga Usaha Tani (RTUT) Berdasarkan Luas Lahan Garapan

Berdasarkan hasil pendataan usaha tani tahun 2009 yang dilakukan oleh Badan Pusat Statistik (BPS) maka dihasilkan data RTUT berdasarkan 4 kategori luas lahan. 
Tabel6.

Jumlah Rumah Tangga Usaha Tani (RTUT) Indonesia

Per 2009 Menurut Penguasaan Lahan

\begin{tabular}{|c|c|c|c|c|c|}
\hline \multirow{2}{*}{ Jumlah RTUT } & \multicolumn{5}{|c|}{ Golongan Luas Lahan Yang Dikuasai (hektar) } \\
\cline { 2 - 6 } & $<0,5$ & $0,5-1,99$ & $\begin{array}{c}\leq 1,99 \\
(\text { kolom } 2+3)\end{array}$ & \multicolumn{2}{l}{$\begin{array}{c}\text { Jumlah (kolom } \\
4+5)\end{array}$} \\
\hline 1 & 2 & 3 & 4 & 5 & 6 \\
\hline 17.830 .832 & 9.205 .879 & 9.978 .584 & 16.184 .463 & 1.646 .369 & 17.830 .832 \\
\hline
\end{tabular}

Sumber: PUT BPS 2009 (2010).

2. Jumlah Rumah Tangga Usaha Tani (RTUT) Berdasarkan Komoditas PJKT

Rumah tangga usaha tani merupakan varian rumah tangga Indonesia yang menggarap usaha tani pada komoditas-komoditas tertentu yaitu komoditas padi, jagung, kedelai, dan tebu (PJKT) berdasarkan hasil pendataan usaha tani tahun 2009 yang dilakukan oleh Badan Pusat Statistik (BPS).

Tabel 7.

Jumlah Rumah Tangga Usaha Tani (RTUT) Indonesia

Per 2009 Menurut Jenis Tanaman Yang Diusahakan

\begin{tabular}{|c|c|c|c|c|}
\hline \multirow{2}{*}{ Jumlah RTUT } & \multicolumn{4}{|c|}{ Jenis Tanaman Dari Petani PJKT } \\
\cline { 2 - 5 } & Padi & Jagung & Kedelai & Tebu \\
\hline 17.830 .832 & 14.992 .137 & 6.714 .695 & 1.164 .477 & 195.459 \\
\hline Proporsi & $84,07 \%$ & $37,65 \%$ & $6,53 \%$ & $1,09 \%$ \\
\hline
\end{tabular}

Sumber: PUT BPS 2009 (2010).

\section{Jumlah Musim Tanam Masing-Masing Komoditas PJKT}

Menurut Sumarno (2006), untuk periodesasi musim tanam padi itu dikelompokkan menjadi 3 periode tanam yaitu: musim tanam utama, musim tanam gadu dan musim tanam kemarau. Sedangkanmenurut Lilik Slamet dkk (2014), untuk musim tanam padi dan jagung adalah sebanyak 2 kali dalam setahun sedangkan kedelai sebayak 3 kali dalam setahun. Dalm hal ini, penulis lebih memilih frekwensi maksimal dalam perhitungan subsidi sehingga khusus untuk padi penulis memilih musim tanam padi sebanyak 3 kali sebagai mana dijelaskan Sumarno (2006) di atas. Adapun tanaman tebu, dari berbagai sumber terutama Kementerian Pertanian mengimpisitkan bahwa musim tanam tebu adalah hanya 1 kali dalam setahun (Kementan, 2013).

4. Besaran Premi Asuransi

Jika mengacu pada best practices di atas maka tidak ada angka yang standar yang diterapkan oleh setiap negara. Besaran premi asuransi bergantung pada kondisi wilayah, kemampuan petani untuk membayar, dan lain sebagainya. Oleh karena itu, pada penelitian ini penulis mengacu pada besaran premi yang diterapkan pada uji coba asuransi pertanian tahun 2013 karena besaran premi tersebut (Rp 180.000) pasti sudah melalui kajian yang mendalam dari Pemerintah dan pihak terkait lainnya.

5. Porsi Subsidi Premi yang Diberikan Pemerintah

Setelah kajian ini memilih besaran premi maka yang harus ditentukan berikutnya adalah besaran porsi subsidi dari premi tersebut. Pada kajian ini, penulis membuat tiga alternatife skenario porsi subsidi pemerintah yaitu 10\%, 30\%, dan 50\% dari premi. Angka simulasi sementara ini berguna untuk memprediksi besaran subsidi APBN yang harus dikeluarkan oleh pemerintah. 
Setelah variabel untuk menetukan besaran subsidi premi asuransi pertanian telah ditentukan maka besaran subsidi premi asuransi pertanian untuk masing-masing kategori luasan lahan dapat dirumuskan sebagai berikut:

$$
S_{-} P_{r_{t}} P_{-} \text {Lahan }_{I-J}=\sum_{I-J} \alpha_{1} P \_P J K T_{t-n} \bullet \alpha_{2} M \_P J K T_{t-n} \bullet \alpha_{3} P r_{t-n}
$$

Dari perhitungan rumus matematika tersebut maka dengan besaran premi sebesar Rp180.000,akan menghasilkan angka besaran subsidi premi yang akan dibayar pemerintah melalui subsidi APBN kepada petani Indonesia berdarkan luasan lahan adalah seperti tampak pada tabel 8,9, dan 10 pada skenario 1,2, dan 3 huruf A sampai dengan huruh L. Jadi dengan data riil dan asumsi yang digunakan maka pemerintah mempunyai 12 alternatif besaran subsidi premi yang akan dibayarkan.

Tabel 8.

Skenario 1: Subsidi Premi Dengan Porsi Subsidi 10\% (=Rp18.000,-)

\begin{tabular}{|c|c|c|c|c|c|c|c|}
\hline \multirow{2}{*}{$\begin{array}{c}\text { Alternatif } \\
\text { berdasarkan } \\
\text { Luasan } \\
\text { Lahan }\end{array}$} & \multicolumn{3}{|c|}{ Jumlah Petani } & \multicolumn{3}{c|}{$\begin{array}{c}\text { Proporsi Jumlah Petani PJKT dan } \\
\text { Jumlah Musim Panen PJKT }\end{array}$} & \multicolumn{2}{c|}{$\begin{array}{c}\text { Alternatif Alokasi } \\
\text { Kepemilikan } \\
\text { Luas Lahan } \\
\text { (Hektar) }\end{array}$} & Orang & $\begin{array}{c}\text { Padi } \\
(84,07 \%) \\
3 \mathrm{kali}\end{array}$ & $\begin{array}{c}\text { Jagung } \\
(37,65 \%) \\
2 \mathrm{kali}\end{array}$ & $\begin{array}{c}\text { Kedelai } \\
(6,53 \%) \\
3 \mathrm{kali}\end{array}$ & $\begin{array}{c}\text { Tebu } \\
(1,09 \%) \\
1 \mathrm{kali}\end{array}$ & $\begin{array}{c}\text { Yang Dibayar } \\
\text { (Rupiah/Tahun) }\end{array}$ \\
\hline $\mathrm{A}$ & $<0.5 \mathrm{H}$ & 9.205 .879 & 7.739 .382 & 3.466 .013 & 601.144 & 100.344 & 576.971 .101 .622 \\
\hline $\mathrm{B}$ & $\begin{array}{c}\geq 0.5 \mathrm{sd}<2 \\
\mathrm{H}\end{array}$ & 6.978 .584 & 5.866 .896 & 2.627 .437 & 455.702 & 76.067 & 437.377 .169 .333 \\
\hline $\mathrm{C}$ & $<2 \mathrm{H}$ & 16.184 .463 & 13.606 .278 & 6.093 .450 & 1.056 .845 & 176.411 & 1.014 .348 .270 .955 \\
\hline $\mathrm{D}$ & $\geq 2$ & 17.830 .832 & 14.990 .380 & 6.713 .308 & 1.164 .353 & 194.356 & 1.117 .533 .130 .934 \\
\hline
\end{tabular}

Sumber: Ilustrasi dan Simulasi Penulis

Tabel 9.

Skenario 2: Subsidi Premi Dengan Porsi Subsidi 30\% (=Rp64.000,-)

\begin{tabular}{|c|c|c|c|c|c|c|c|}
\hline \multirow{2}{*}{$\begin{array}{c}\text { Alternatif } \\
\text { berdasarkan } \\
\text { Luasan } \\
\text { Lahan }\end{array}$} & \multicolumn{3}{|c|}{ Jumlah Petani } & \multicolumn{3}{c|}{$\begin{array}{c}\text { Proporsi Jumlah Petani PJKT dan } \\
\text { Jumlah Musim Panen PJKT }\end{array}$} & \multicolumn{2}{c|}{$\begin{array}{c}\text { Alternatif Alokasi } \\
\text { Angaran Subsidi } \\
\text { Luas Lahan } \\
\text { (Hektar) }\end{array}$} & Orang & $\begin{array}{c}\text { Padi } \\
(84,07 \%) \\
3 \mathrm{kali}\end{array}$ & $\begin{array}{c}\text { Jagung } \\
(37,65 \%) \\
2 \mathrm{kali}\end{array}$ & $\begin{array}{c}\text { Kedelai } \\
(6,53 \%) \\
3 \mathrm{kali}\end{array}$ & $\begin{array}{c}\text { Tebu } \\
(1,09 \%) \\
1 \mathrm{kali}\end{array}$ & $\begin{array}{c}\text { Yang Dibayar } \\
\text { (Rupiah/Tahun) }\end{array}$ \\
\hline $\mathrm{E}$ & $<0.5 \mathrm{H}$ & 9.205 .879 & 7.739 .382 & 3.466 .013 & 601.144 & 100.344 & 2.051 .452 .805 .766 \\
\hline $\mathrm{F}$ & $\begin{array}{c}\geq 0.5 \mathrm{sd}<2 \\
\mathrm{H}\end{array}$ & 6.978 .584 & 5.866 .896 & 2.627 .437 & 455.702 & 76.067 & 1.555 .118 .824 .294 \\
\hline $\mathrm{G}$ & $<2 \mathrm{H}$ & 16.184 .463 & $13,606,278$ & 6.093 .450 & 1.056 .845 & 176.411 & 3.606 .571 .630 .061 \\
\hline $\mathrm{H}$ & $\geq 2$ & 17.830 .832 & $14,990,380$ & 6.713 .308 & 1.164 .353 & 194.356 & 3.973 .451 .132 .211 \\
\hline
\end{tabular}

Sumber: Ilustrasi dan Simulasi Penulis 
Tabel 10.

Skenario 3: Subsidi Premi Dengan Porsi Subsidi 50\% (=Rp90.000,-)

\begin{tabular}{|c|c|c|c|c|c|c|c|}
\hline \multirow{2}{*}{$\begin{array}{l}\text { Alternatif } \\
\text { berdasarkan } \\
\text { Luasan } \\
\text { Lahan }\end{array}$} & \multicolumn{2}{|c|}{ Jumlah Petani } & \multicolumn{4}{|c|}{$\begin{array}{l}\text { Proporsi Jumlah Petani PJKT dan } \\
\text { Jumlah Musim Panen PJKT }\end{array}$} & \multirow{2}{*}{$\begin{array}{l}\text { Alternatif Alokasi } \\
\text { Anggaran Subsidi } \\
\text { Yang Dibayar } \\
\text { (Rupiah/Tahun) }\end{array}$} \\
\hline & $\begin{array}{c}\text { Kepemilikin } \\
\text { Luas Lahan } \\
\text { (Hektar) }\end{array}$ & Orang & $\begin{array}{c}\text { Padi } \\
(84,07 \%) \\
3 \mathrm{kali}\end{array}$ & $\begin{array}{c}\text { Jagung } \\
(37,65 \%) \\
2 \mathrm{kali}\end{array}$ & $\begin{array}{c}\text { Kedelai } \\
(6,53 \%) \\
3 \mathrm{kali}\end{array}$ & $\begin{array}{c}\text { Tebu } \\
(1,09 \%) \\
1 \mathrm{kali}\end{array}$ & \\
\hline I & $<0.5 \mathrm{H}$ & 9.205 .879 & 7.739 .382 & 3.466 .013 & 601.144 & 100.344 & 2.884 .855 .508 .109 \\
\hline $\mathrm{J}$ & $\begin{array}{c}\geq 0.5 \mathrm{sd}<2 \\
\mathrm{H}\end{array}$ & 6.978 .584 & 5.866 .896 & 2.627 .437 & 455.702 & 76.067 & 2.186 .885 .846 .664 \\
\hline K & $<2 \mathrm{H}$ & 16.184 .463 & $13,606,278$ & 6.093 .450 & 1.056 .845 & 176.411 & 5.071 .741 .354 .773 \\
\hline $\mathrm{L}$ & $\geq 2$ & 17.830 .832 & $14,990,380$ & 6.713 .308 & 1.164 .353 & 194.356 & 5.587 .665 .654 .672 \\
\hline
\end{tabular}

Sumber: Ilustrasi dan Simulasi Penulis

Pada tabel di atas terlihat bahwa alokasi anggaran subsidi premi yang harus dikeluarkan pemerintah adalah dari yang terkecil Rp 576.971.101.622,- sampai dengan maksimal Rp 5.587.665.654.672,- Hal ini tergantung pada petani kategori manakah yang akan disasar program asuransi petanian ini dan berapa porsi subsidi premi yang akan diambil.

Di sampng itu, selama tidak begitu membebani APBN maka bantuan pemerintah kepada petani, kelompok petani yang menjadi peserta asuransi pertanian ini diharapkan tidak hanya terkait dengan pemberian subsidi premi tapi dapat juga berupa dukungan untuk penelitian dan pembangunan (litbang) produksi pertanian, capacity building bagi para petani, pemberian informasi, pemetaan risiko, dan lain sebagainya.Subsidi/bantuan pemerintah tersebut dapat diperoleh dari realokasi anggaran beberapa belanja subsidi yang selama ini dianggap kurang menyentuh petani lansung namun diduga justru menguntungkan perusahaan-perusahaan besar seperti pada program pemberian subsidi pupuk dan benih.

Sebagai tambahan, sebenarnya yang juga lebih penting disamping adanya perlindungan terhadap segala risiko terhadap gagal panen adalah adanya jaminan terjaganya nilai jual hasil usaha tani paska panen (jaminan harga) agar tetap stabil dan diatas biaya keekonomian yang dikeluarkan sehingga para petanidapat memperoleh keuntungan yang dapat menyejahterakanhidupnya.

\section{E. PENUTUP}

\section{Kesimpulan}

Sektor pertanian dan para pelaku usaha di dalamnya berhak mendapat perlindungan dalam menghadapi permasalahan kesulitan memperoleh prasarana dan sarana produksi, kepastian usaha, risiko harga, kegagalan panen, praktek ekonomi biaya tinggi, dan perubahan iklim. Pelajaran dari best practices negara-negara sampel dan uji coba asuransi di atas, menurut penulis, dapat dijadikan sebagai salah satu landasan dalam pelaksanaan asuransi pertanian di Indonesia di masa yang akan datang dengan mengambil hal-hal yang positif dan mengabaikan hal-hal yang kurang sesuai dengan kondisi Indonesia. 
Dari hasil telah terhadap uji coba dan best practices di beberapa negara tersebut maka ada beberapa poin dan pelajaran yang mungkin dapat diterapkan di Inonesia, antara lain bahwa pelaksanaan uji coba asuransi pertanian di Indonesia pada tahun lalu khususnya di Kabupaten Jombang sebenarnya telah menunjukkan keseriusan pemerintah dan pihak terkait dalam melindungi petani dan usahanya dari risiko gagal panen. Jika dilihat dari uji coba di atas, sebenarnya petani diuntungkan dengan kecilnya premi yang harus dibayarkan (hanya 20 persen dari Rp180.000,-) permusim tanam dibanding dengan risiko yang mungkin harus ditanggung yaitu gagal panen.

Disamping itu, besaran premi, nilai yang asuransi dan klaim bisa sangat variatif tergantung pada kondisi wilayah, petani dan lainnya sebagaimana praktek penerapan di India. Pemerintah juga dapat berperan dalam meringankan pembayaran premi ini melalui pemberian subsidi yang dapat dialokasikan dalam APBN. Namun demikian, kebijakan pemerintah menggandeng JICA dari Jepang dalam uji coba juga merupakan langkah terobosan yang baik agar beban APBN dalam menanggung premi dapat diminimalisir jika nantinya asuransi pertanian benar-benar akan diterapkan di Indonesia.

Pada sisi lain, luasan lahan yang diasuransikan bisa disesuaikan dengan kondisi wilayah, kesepakatan petani dan pihak perusahaan, serta kondisi lainnya. Hal ini berarti dalam penentuan luasan lahan yang diasuransikan adalah sangat fleksibel. Begitu juga dengan adanya diversifikasi produk asuransi pertanian kemungkinan dapat mempermudah pelaksanaan program ini ke depannya karena memberikan alternatif pilihan bagi para petani di berbagai wilayah di Indonesia.

Yang terakhir adalah bahwa melibatkan banyak perusahaan asuransi dan re-asuransi dalam implementasi asuransi pertanian barangkali dapat menjadi salah satu terobosan untuk terciptanya suatu kompetisi pasar yang sempurna yang dapat menguntungkan berbagai pihak terutama petani dan pada gilirannya dapat melindungi hasil usaha tani Indonesia secara lebih baik.

Dalam artikel ini, penulis merekomendasikan suatu bentuk mekanisme pengelolaan asuransi pertanian di Indonesia dan perhitungan potensi dampaknya pada APBN jika asuransi pertanian ini diterapkan dengan berbagai alternatif besaran subsidi berdasarkan alternatif variabel yang dipilih oleh pemerintah.

\section{Rekomendasi}

Dari pembahasandi atas ada beberapa poin yang mungkin dapat direkomendasikan di kajian ini yaitu:

1. Perlu adanya keseriusan pemerintah dan pihak terkait dalam melindungi petani dan usahanya dari risiko gagal panen diantaranya adalah dengan jalan mengimplementasikan asuransi pertanian;

2. Merujuk pada mekanisme pengelolaan asuransi pertanian yang penulis rekomendasikan maka pemeritah perlu mendorong keterlibatan secara aktif pihak-pihak terkait serta mengawasi kinerja pihak-pihak tersebut;

3. Pemerintah juga dapat menggandeng lembaga lain (atau seperti avalist di tingkat petani dengan kerja sama yang saling menguntungkan) yaitu dapat berupa pembagian beban dalam pemberian subsidi premi kepada para petani dengan kompensasi berhak membeli produk hasil panen petani yang menguntungkan semua pihak dengan tidak ada intervensi atau kepentingan sepihak;

4. Melibatkan banyak perusahaan asuransi dan re-asuransi dalam implementasi asuransi yang dapat menjadi salah satu terobosan untuk terciptanya suatu kompetisi pasar yang sempurna yang dapat menguntungkan berbagai pihak terutama petani dan pada akhirnya dapat melindungi hasil usaha tani Indonesia secara lebih baik.

5. Pemerintah juga hendaknya menjamin terjaganya nilai jual hasil usaha tani paska panen (jaminan harga) agar tetap stabil dan diatas biaya keekonomian yang dikeluarkan; 
6. Guna mendukung rekomendasi nomor 2,3, dan 4 maka pemerintah hendaknya membentuk komite kebijakan yang beranggotakan perwakilan dari semua pihak yang telibat dalam asuransi pertanian ini.

\section{Implikasi Kebijakan}

Rencana diimplementasikannya program asuransi pertanian ini tentunya akan berdampak pada penambahan alokasi belanja negara pada APBN khususnya pada anggaran subsidi yang di mana pengeluaran subsidi ini bertujuan untuk meringankan pembayaran premi asuransi yang dibayarkan oleh pemerintah.

\section{DAFTAR PUSTAKA}

Aziz, Abdul. (2013).Upaya Optimalisasi Penyerapan Kredit Sektor Pertanian, Majalah Info Risiko Fiskal, Edisi 2 Tahun 2013, Badan Kebijakan Fiskal, Kementerian Keuangan;

Aziz, Abdul. (2014).KKPE: Karakteristik, Nilai Tambah, dan Kendala Implementasinya dalam buku Program Pembiayaan Sektor Pertanian, Badan Kebijakan Fiskal, Kementerian Keuangan;

Andrayani, Dian. (2013). Asuransi Pertanian Sebagai Sarana Meningkatkan Kesejahterahan Petani, Institut Pertanian Bogor, tersedia secara online di http://repository.ipb.ac.id/bitstream/ handle/123456789/63848/H13dan.pdf?sequence=1;

Badan Pusat Statistik. (2010).Hasil Pendataan Usaha Tani 2009 (PUT 2009), Badan Pusat Statistik;

Direktorat Sistim Manajemen Informasi, Ditjen Perbendaharaan Kementerian Keuangan. (2014).Perkembangan Subsidi Kredit Program 2005-2014, Direktorat SMI, tidak dipublikasikan;

Direktorat Jenderal Anggaran Kementerian Keuangan. (2015).Buku Saku APBN dan Indikator Ekonomi 2015, Direktorat Jenderal Anggaran Kementerian Keuangan;

Direktorat Pangan dan Pertanian badan Perencanaan Pembangunan Nasional. (2013), Studi Pendahuluan Rencana Pembangunan jangka Menengah Nasional (RPJMN) Bidang Pangan dan Pertanian 2015-2019, Available online athttp://www.bappenas.go.id/files/ 3713/9346/9271/RPJMN_Bidang_Pangan_dan_Pertanian_2015-2019.pdf;

Setiawan, Hadi dan Sofi AD. (2014), Memilih Skema Asuransi Pertanian, Available online

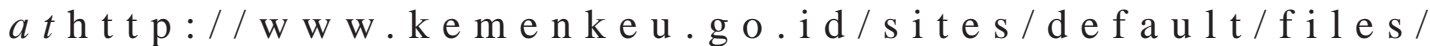
Memilih\%20Skema\%20Asuransi\%20Pertanian\%20.pdf;

Idris Soentoro, Ali. (2005).Metode Penelitian Dengan Aplikasi Statistik, Jakarta, Pasca Sarjana Universitas Budi Luhur;

Insyafiahdan Indria Wardhani. (2014). Kajian Persiapan Implementasi Asuransi Pertanian Secara Nasional, Badan Kebijakan Fiskal, Kementerian Keuangan, Available online athttp:// www.kemenkeu.go.id/sites/default/files/Kajian\%20Persiapan\%

20Implementasi\%20Asuransi\%20Pertanian.pdf;

Kementerian Pertanian. (2013).Budidaya Tebu, Available online athttp://epetani.pertanian.go.id/ berita/budidaya-tebu-7825; 
Lilik Slamet S, hariadi T.E, Mezak A. Ratag, Erna S. Adiningsih, (TT), Analisis Curah Hujan dan Suhu Untuk Menyusun Pola Tanam Tanaman Pangan di Jawa Barat, diakses 2014, Available online atfile:///C:/Users/user/Downloads/1497-1360-2-PB.pdf;

M.Bielza Diaz-Caneja, C.G. Conte, F.J. Gallego Pinila, J. Stroblmair, R. Catenaro and C. Dittmann. (2009). Risk Management and Agricultural Insurance Schemes in Europe, JRC European Comission, Available online at: http://ec.europa.eu/dgs/jrc/downloads/jrc_reference_ report_2009_09_agri_ins.pdf;

Mahul, Ulivier and Stutley, Charles J. (2010).Government Support to Agricultural Insurance: Challenges and Options for Developing Countries, The World Bank, Available online at: file://C:/Users/user/Downloads/6037.pdf;

Pasaribu, Sahat M, Iwan Setiadji, Nur Khoiriyah Agustin, Erna maria Lokollo, Herlina tarigan, Juni Hestina, Yana Supriyatna.(2010).Pengambangan Asuransi Usahatani Padi Untuk Menaggulangi Risiko Kerugian 75\% Akibat Banjir, Kekeringan dan Hama Penyakit, Kementrian Pertanian, Available online athttp://pse.litbang. pertanian.go.id/ind/pdffiles/ MAKPROP_SHP.pdf;

Tahir, Arifin. (2011).Kebijakan Publik dan Transparansi Penyelenggaraan Pemerintah Daerah, Penerbit PT Pustaka Indonesia Press, Jakarta, Available online athttp://repository. ung.ac.id/ get/karyailmiah/89/KEBIJAKAN-PUBLIK-D AN-TRANSPARANSIPENYELENGGARAAN-PEMERINTAHAN-DAERAH.pdf.

S.S Raju and Rames Chand.(2008). Agricultural Insurance in india Problems and Prospects, India, National Centre for Agricultural Economics and Policy Research (India Council of Agricultural Research), Available online at: http://www.ncap. res.in/upload_files/others/ oth_15.pdf;

Sumarno, (2006).Periodesasi Musim Tanam Padi Sebagai Landasan Manajemen Produksi Beras Nasional. Dimuat pada Sinar tani No. 3136 Tahun 2006, Available online at di http://203.176.181.70/bppi/lengkap/st080206-1.pdf;

The World Bank (2010).Agricultural Insurance in Latin America, Developing the Market, Desember, Available online at: http://siteresources.worldbank.org/ FINANCIALSECTOR/ Resources/Agricultural_insurance_in_LAC_web_FINAL.pdf;

Undang-Undang Republik Indonesia Nomor 19 Tahun 2013 Tentang Perlindungan dan Pemberdayaan Petani. 